Edubiotik: Jurnal Pendidikan, Biologi dan Terapan

ISSN 2528-679X (print), ISSN 2597-9833 (online)

Volume 4, Nomor 02, Tahun 2019, Hal. 75 - 82

Available online at:

http://ejurnal.budiutomomalang.ac.id/index.php/edubiotik

\title{
Efektifitas penerapan model pembelajaran kooperatif tipe students team achievement division dalam meningkatkan aktivitas dan hasil belajar kognitif siswa
}

\author{
Rahmat Saleh, Filawati \\ D3 Analisis Kesehatan, Universitas Indonesia Timur, Makassar, Indonesia \\ E-mail: rahmatsaleh2017@gmail.com*, filawati1289@gmail.com
}

\begin{tabular}{|c|c|}
\hline Informasi Artikel & ABSTRACT \\
\hline $\begin{array}{l}\text { Submit: } \\
04-07-2019 \\
\text { Diterima: } \\
21-08-2019 \\
\text { Dipublikasikan: } \\
01-09-2019\end{array}$ & $\begin{array}{l}\text { The low activity and cognitive learning outcomes of Grade VIIIB MTs Aisyiyah } \\
\text { students require innovation in learning by using cooperative learning models. } \\
\text { This study aims to determine the increase in activities and learning outcomes } \\
\text { in biology through the application of cooperative learning models of students } \\
\text { team achievement division class VIIIB MTs Aisyiyah Sungguminasa Kab. } \\
\text { Gowa. This type of research is Classroom Action Research which consists of } \\
\text { two cycles. The subjects of the study were students of class VIIIB MTs } \\
\text { Aisyiyah Sungguminasa Kab. Gowa. The research instrument was an } \\
\text { observation sheet and a test. Data analysis techniques with qualitative } \\
\text { descriptive statistical analysis for student activities and analyzed with } \\
\text { quantitative descriptive statistical analysis for learning outcomes. The results } \\
\text { showed that there was an increase in students' cognitive learning activities } \\
\text { and outcomes namely from cycle } 1 \text { and cycle } 2 \text { with an average value of } \\
46.71 \% \text { and } 85.5 \% \text {. Thus, the conclusion of this research is the use of } \\
\text { cooperative learning models of students team achievement division type can } \\
\text { increase the activities and learning outcomes of students of class VIIIB MTs } \\
\text { Aisyiyah Sungguminasa Kab. Gowa. } \\
\text { Key words: Activities, Learning outcomes, Student team achievement } \\
\text { division }\end{array}$ \\
\hline Penerbit & ABSTRAK \\
\hline $\begin{array}{l}\text { Program Studi } \\
\text { Pendidikan Biologi, } \\
\text { Fakultas Pendidikan } \\
\text { Ilmu Eksakta dan } \\
\text { Keolahragaan, IKIP } \\
\text { Budi Utomo, Malang, } \\
\text { Indonesia }\end{array}$ & $\begin{array}{l}\text { Rendahnya aktivitas dan hasil belajar kognitif siswa kelas VIIIB MTs Aisyiyah } \\
\text { menuntut adanya inovasi pembelajaran dengan menggunakan model } \\
\text { pembelajaran kooperatif. Penelitian in bertujuan untuk mengetahui } \\
\text { peningkatan aktivitas dan hasil belajar biologi melalui penerapan model } \\
\text { pembelajaran kooperatif tipe student team achievement divisionkelas VIIIB } \\
\text { MTs Aisyiyah Sungguminasa Kab. Gowa. Jenis penelitian ini adalah } \\
\text { Penelitian Tindakan Kelas yang terdiri dari dua siklus. Subjek penelitian } \\
\text { adalah siswa kelas VIIIB MTs Aisyiyah Sungguminasa Kab. Gowa. Instrumen } \\
\text { penelitian adalah lembar observasi dan tes. Teknik analisis data dengan } \\
\text { analisis statistik deskriptif kualitatif untuk aktivitas siswa dan dianalisis dengan } \\
\text { analisis statistik deskriptif kuantitatif untuk hasil belajar. Hasil penelitian } \\
\text { menunjukkan bahwa ada peningkatan aktivitas dan hasil belajar kognitif siswa } \\
\text { yaitu dari siklus } 1 \text { dan siklus } 2 \text { dengan nilai rata-rata } 46,71 \% \text { dan } 85,5 \% \text {. } \\
\text { Dengan demikian, simpulan penelitian ini adalah penggunaan model } \\
\text { pembelajaran kooperatif tipe student team achievement divisiondapat } \\
\text { meningkatkan aktivitas dan hasil belajar siswakelas VIIIB MTs } \\
\text { AisyiyahSungguminasa Kab. Gowa. } \\
\text { Kata kunci: Aktivitas, Hasil belajar, Students team achievement division }\end{array}$ \\
\hline
\end{tabular}

This Edubiotik: Jurnal Pendidikan, Biologi dan Terapan is licensed under a CC BY-SA (Creative Commons Attribution-ShareAlike 4.0 International License) 


\section{PENDAHULUAN}

Pengembangan sumber daya manusia di bidang pendidikan merupakan sarana dan wahana yang sangat penting dalam menciptakan masyarakat yang unggul dan berdaya saing. Oleh karena itu bidang pendidikan perlu dan harus mendapatkan perhatian, penanganan, dan prioritas secara sungguh-sungguh baik oleh pemerintah, masyarakat pada umumnya dan para pengelola pendidikan pada khususnya. Kemajuan suatu bangsa ditentukan oleh sumber daya manusia yang unggul. Proses pendidikan, khususnya di Indonesia selalu mengalami suatu penyempurnaan yang pada akhirnya menghasilkan suatu produk atau hasil pendidikan yang berkualitas. Berbagai usaha telah dilakukan oleh pengelolah pendidikan untuk memperoleh kualitas atau kuantitas pendidikan dalam rangka meningkatkan prestasi belajar siswa atau peser tadidik. Langkah ini merupakan langkah awal untuk meningkatkan kualitas sumber daya manusia. Pendidikan menciptakan sumber daya manusia yang berkulaitas dan berdaya saing (Riyanto \& Susilawati, 2019).

Sebagai penggerak pendidikan yang terdepan yaitu guru yang memiliki tanggungjawab besar dalam menciptakan sumber daya manusia yang unggul. Guru pada hakikatnya merupakan tenagakependidikan yang memikul berat tanggung jawab kemanusiaan sehingga menuntut profesionalitas tinggi dalam proses pembelajaran melalui kompetensi profesionalnya guru harus mampu mewujudkan langkah-langkah pembelajaran yang inovatif, progresif dan kreatif, memahami dan mempraktekkan kurikulum yang berlaku serta menggunakan metode pembelajaran yang sesuai. Namun, kenyataan di lapangan masih ada guru yang tidak melakukan metode atau model yang disarankan dalam mengajar karena belum paham betul terhadap metode atau model tersebut sehingga mereka tetap melakukan metode atau model lama. Guru yang aktif dalam mengajar sedangkan siswanya hanya menerima apa yang dikatakan gurunya (pasif), padahal dalam kurikulum sekarang siswa seharusnya yang paling aktif dalam belajar. Demikian halnya yang terjadi disekolah MTs. Aisyiyah Sungguminasa Kab. Gowa, berdasarkan hasil observasi pada tanggal 22 September 2011 dengan guru biologi MTs. Aisyiyah Sungguminasa Kab. Gowa, khususnya kelas VIIInilai hasil belajar biologi kognitifsiswa dikategorikan rendah, yaitu 56,79 masih dibawah standar ketuntasan belajar yaitu sebesar 65 . Alternatif pemecahan masalah tersebut adalah model pembelajaran yang mampu mengaktifkan peserta didik dalam proses belajar mengajaragar lebih menyenangkan dan merasa lebih percaya diri akan kemampuan yang mereka miliki. Pembelajaran kooperatif merupakan sebuah kelompok strategi pengajaran yang melibatkan siswa bekerja secara berkolaborasi untuk mencapai tujuan bersama (Slavin, 1995).

Model pembelajaran kooperatif mengalami perkembangan sehingga muncul berbagai macam tipe model pembelajaran kooperatif. Salah satu di antaranyaadalah model pembelajaran kooperatif tipe students team achievement division. Model pembelajaran kooperatif tipe students team achievement division adalah salah satu solusi untuk mengaktifkan siswa, didalamnya siswa diberi kesempatan untuk berkolaborasi dengan teman sebaya dalam bentuk diskusi kelompok untuk memecahkan suatu permasalahan. Masing-masing kelompok beranggotakan empat atau lima orang siswa yang mempunyai kemampuan akademik,jenis kelamin dan lain-lain yang heterogen, sehingga dalam satu kelompok akan terdapat kemampuan 
akademik dan jenis kelamin yang berbeda sehingga lebih memugkinkan akan memberikan kontribusi dan komunikasi antar siswa akan lebih baik (Slavin, 1995).

Efektivitas penerapan model pembelajaran kooperatif tipe students team achievement division dalam meningkatkan hasil belajar dibuktikan melalui hasil penelitian yang terdahulu menyatakan bahwa terdapat perbedaan hasil belajar siswa yang mengikuti model pembelajaran koperatif tipe students team achievement division dengan siswa yang mengikuti model pembelajaran konvensional serta penerapan pembelajaran model students team achievement division dapat meningkatkan hasil belajar siswa (Suardi, Marhaeni, \& Dantes, 2014; Lubis, 2012; Purba, 2011). Berdasarkan hasil penelitian tersebut maka penerapan model pembelajaran kooperatif tipe students team achievement division merupakan solusi yang tepat yang mampu mengatasi masalah belajar siswa terutama hasil belajar kognitif siswa dan aktivitas belajarn yang terjadi di MTs. Aisyiyah Sungguminasa Kab. Gowa. Tujuan dari penelitian ini yaitu untuk mengetahui aktivitas belajar dan hasil belajar kognitif siswa dengan penerapan model pembelajaran kooperatif tipe STAD.

\section{METODE PENELITIAN}

Jenis penelitian yang digunakan adalah Penelitian Tindakan Kelas (PTK). Penelitian Tindakan Kelas merupakan penelitian yang terdiri dari dua siklus dan setiap siklus terdiri dari empat tahapan yaitu perencanaan, pelaksanaan tindakan, pengamatan, dan refleksi. Penelitian akan dilanjutkan apabila pada siklus sebelumnya belum mencapai indikator yang diharapkan (Endaningsih, Maryani, \& Sukawismani, 2012). Penelitian ini mengggunakan rencana Penelitian Tindakan Kelas yang diadaptasi oleh Kemmisdan MC Taggart dalam Wiriatmadja (2008) yang dimodifikasi sesuai dengan kebutuhan. Alasannya karena penelitian ini dilakukan secara kolaboratif reflektif dalam situasi yang riil guna mencari dasar bagi kebutuhan praktis khususnya dalam peningkatan aktivitas dan hasil belajar Biologi melalui model pembelajaran tipe students team achievement division terhadap siswa kelas VIIIB MTs Aisyiyah Sungguminasa Kab. Gowa. Subjek pada penelitian ini adalah siswa kelas VIIIB MTs Aisyiyah Sungguminasa Kab.Gowa, dengan jumlah siswa 38 orang yang terdiri dari 17 siswa laki-laki dan 21 siswa perempuan. Indikator keberhasilan dari segi aktivitas adalah terjadinya peningkatan persentase atau jumlah siswa yang melakukan setiap komponen aktivitas yang menjadi bahan pengamatan peneliti dan observer pada saat proses pembelajaran dari siklus I ke siklus II yang dikumpulkan dengan lembar observasi. Indikator keberhasilan dari segi hasil belajar adalah bila dari persentase dan frekuensi hasil tes siswa dapat mencapai ketuntasan minimal $65 \%$.

Data yang diperoleh mengenai hasil belajar siswa dianalisis dengan menggunakan dua cara yaitu analisis statistik deskriptif kualitatif digunakan untuk mendeskripsikan ke aktifan siswa pada setiap siklus dengan melakukan penilaian secara verbal (aktivitas dan sikap yang teramati oleh observer). Analisis statistik deskriptif kualitatif belum dapat memberikan jawaban yang cukup tentang hasil belajar yang diperoleh siswa. Sedangkan analisis data kuantitatif digunakan apabila data yang dikumpulkan berwujud angka atau diwujudkan dengan angka (Asmani, 
2011). Data hasil belajar siswa berupa tes akan dianalisis dengan menggunakan analisis statistic deskriptif kuantitatif dengan mendeskripsikan skor yang berdasarkan penilaian acuan patokan, dihitung berdasarkan skor maksimal yang dicapai oleh siswa. Nilai yang diperoleh selanjutnya dikelompokkan menjadi lima kategori, yaitu sangat tinggi, tinggi, sedang, rendah dan sangat rendah. Arikunto (2005) menjelaskan pedoman pengkategorian hasil belajar siswa yang dapat dilihat pada Tabel 1.

Tabel 1. Pedoman Pengkategorian Hasil Belajar Siswa

\begin{tabular}{cc}
\hline Interval nilai & Kategori \\
\hline $0-34$ & Sangat rendah \\
$35-54$ & Rendah \\
$55-64$ & Sedang \\
$65-84$ & Tinggi \\
\hline $85-100$ & Sangat tinggi \\
\hline
\end{tabular}

\section{HASIL PENELITIAN DAN PEMBAHASAN}

\section{Siklus 1: Gambaran Aktivitas dan Hasil Belajar Siswa}

Hasil pengamatan siswa pada siklus I menunjukan bahwa 6 indikator yang direncanakan telah ditetapkan dalam kegiatan belajar siswa, banyaknya siswa yang melakukan indikator pertama berjumlah 35 siswa $(92,1 \%)$, indikator kedua berjumlah 26 siswa $(68,4 \%)$, indikator ketiga berjumlah 19 siswa $(50 \%)$, indikator keempat siswa tidak melakukan aktifitas mempelajari pelajaran lain saat kerja kelompok berlangsung. Selanjutnya, indikator kelima berjumlah 11 siswa (28,9\%), sedangkan pada indikator keenam juga tidak ada aktfitas yang dilakukan siswa. Dari hasil pengamatam tersebut dapat di lihat persentase bahwa siswa yang aktif dalam kelompok saat mencari jawaban mencapai $92,1 \%$, yang mengajukan pertanyaan saat presentase kelompok mencapai $68,4 \%$; selanjutnya yang aktif menjawab pertanyaan dari kelompok lain saat presentase hasil kerja kelompok mencapai 50\% siswa yang belajar pelajaran lain saat kerja kelompok berlangsung tidak ada dan yang aktif berdiskusi dengan teman kelompoknya $28,9 \%$ sementara yang meminta bantuan jawaban pada kelompok lain tidak ada. Rata-rata aktivitas siswa sebesar $47,8 \%$. Analisis kuantitatif menunjukan pencapaian hasil belajar biologi siswa dalam pembelajaran kooperatif tipe students team achievement division pada siklus I. Hasil belajar biologi pada siklus I masih menunjukan kekurangan dan perlu diadakan perbaikan dari segi pengorganisasian pembelajaran. Hasil belajar siswa masih tergolong rendah. Adapun distribusi frekuensi dan presentase hasil belajar biologi siswa kelas VIIIB MTs. Aisyiyah Sungguminasa Kab. Gowa pada siklus I dapat dilihat pada Tabel 2 berikut.

Tabel 2. Distribusi Frekuensi dan Persentase hasil Belajar Siswa kelas VIIIBMTs Aisyiyah Sungguminasa Kabupaten Gowa pada siklus 1

\begin{tabular}{cccc}
\hline Nilai & Frekuensi & Persentase & Kategori \\
\hline $0-34$ & 6 & 15.78 & Sangat rendah \\
$35-54$ & 20 & 52.63 & Rendah \\
$55-64$ & 8 & 21.05 & Sedang \\
$65-84$ & 4 & 10.52 & Tinggi \\
$85-100$ & - & - & Sangat tinggi \\
Jumlah & $\mathbf{3 8}$ & $\mathbf{1 0 0}$ & \\
\hline
\end{tabular}

78 Rahmat Saleh, Filawati - Efektifitas penerapan model pembelajaran kooperatif ... 
Tabel di atas memperlihatkan distribusi nilai yang didapatkan siswa pada siklus I masih ada siswa yang memperoleh nilai dalam kategori rendah sebanyak 20 Orang siswa dengan presentase $(52,63 \%)$, dan kategori sedang berjumlah 8 orang dengan presentase $(21,05 \%)$, sedangkan pada kategori tinggi berjumlah 4 Orang dengan presentase $(10,52 \%)$, dan kategori sangat tinggi tidak ada. Hasil belajar biologi siswa kelas VIIIB MTs. Aisyiyah Sungguminasa Kab. Gowa setelah mengadakan proses pembelajaran kooperatif Tipe students team achievement division siklus I berada pada kategori rendah. Hal ini terlihat pada skor rata-rata yang diperoleh seluruh siswa pada siklus ini adalah 46,71.

\section{Siklus 2: Gambaran Aktivitas dan Hasil Belajar Siswa}

Siklus kedua dilaksanakan selama 3 kali pertemuan, 2 kali pembelajaran materi dan 1 kali pertemuan pemberian tes. Siklus ini dilaksanakan setelah pada siklus 1 indikator kinerja belum tercapai. Dengan demikian sebagai gambaran pelaksanaan siklus ini didasarkan oleh hasil observasi, evaluasi dan refleksi pada siklus 1. Hasil pengamatan siswa pada siklus 6 indikator yang direncanakan telah ditetapkan dalam kegiatan belajar siswa, banyaknya siswa yang melakukan indikator pertama berjumlah 36 siswa $(94,7 \%)$, indikator kedua berjumlah 32 siswa $(84,2 \%)$, indikator ketiga berjumlah 30 siswa $(78,9 \%)$, indikator keempat siswa tidak melakukan aktifitas mempelajari pelajaran lain saat kerja kelompok berlangsung. Selanjutnya, indikator kelima berjumlah 29 siswa (76,3\%), sedangkan pada indikator keenam juga tidak ada aktifitas yang dilakukan siswa pada indikator keenam tersebut. Dari hasil pengamatam tersebut dapat di lihat persentase bahwa siswa yang aktif dalam kelompok saat mencari jawaban mencapai $94,7 \%$, mengajukan pertanyaan saat presentase kelompok mencapai $84,2 \%$; selanjutnya yang aktif menjawab pertanyaan dari kelompok lain saat presentase hasil kerja kelompok mencapai 78,9\%, siswa yang belajar pelajaran lain saat kerja kelompok berlangsung tidak ada dan yang aktif berdiskusi dengan teman kelompoknya $76,3 \%$ sementara yang meminta bantuan jawaban pada kelompok lain tidak ada. Sehingga rata-rata aktivitas siswa pada proses pembelajaran kooperatif tipe students team achievement division adalah $66,8 \%$.

Hasil belajar siswa pada siklus II menunjukkan peningkatan yang signifikan. Hal ini disebabkan banyaknya murid yang aktif dalam kegiatan kelompok dan memahami konsep materi yang diajarkan. Distribusi hasil belajar siklus II dapat dilihat pada Tabel 3.

Tabel 3. Distribusi Frekuensi dan Presentase Hasil Belajar kelas VIII $B$ MTs. Aisyiyah Sungguminasa Kab. Gowa siklus II

\begin{tabular}{cccl}
\hline Nilai & Frekuensi & Persentase & \multicolumn{1}{c}{ Kategori } \\
\hline $0-34$ & 0 & $0 \%$ & Sangat rendah \\
$35-54$ & 0 & $0 \%$ & Rendah \\
$55-64$ & 0 & $0 \%$ & Sedang \\
$65-84$ & 14 & $36.84 \%$ & Tinggi \\
$85-100$ & 24 & $63.15 \%$ & Sangat tinggi \\
\hline Jumlah & $\mathbf{3 8}$ & $\mathbf{1 0 0} \%$ & \\
\hline
\end{tabular}


Berdasarkan Tabel 3 di atas, kategori hasil belajar berada pada level tinggi dan sangat tinggi dengan jumlah siswa masing-masing sebesar 14 orang $(36,84 \%)$ dan 24 orang $(63,15 \%)$. Sedangkan pada kategori rendah, sedang, dan sangat rendah sudah tidak ada atau 0 orang (0\%). Hasil belajar untuk siswa kelas VIIIB MTs. Aisyiyah Sungguminasa Kab. Gowa setelah dilakukan tindakan dengan penerapan pembelajaran kooperatif tipe students team achievement division berada dalam kategori sangat baik dimana skor rata-rata adalah 85,5. Siklus 2 berlangsung 2 kali pertemuan, termasuk tes siklus II. Pada siklus kedua ini, siswa sudah bisa melaksanakan proses pembelajaran kooperatif tipe students team achievement division. Kerjasama antara anggota kelompok mulai terorganisir dengan baik sehingga kegiatan diskusi kelompok terlihat kompak dan berlangsung dengan tertib, suasana yang biasanya kurang aktif pada saat diskusi mulai berkurang. Pada siklus kedua ini, kendala-kendala yang dihadapi siklus I sudah bisa teratasi, siswa yang biasanya sulit menemukan jawaban pada saat pertanyaan muncul mulai berkurang, bahkan siswa yang tadinya pasif sudah mulai aktif. Dari hasil pengamatan ini, memberikan indikasi bahwa perinsip penggunaan pembelajaran kooperatif tipe students team achievement division yang mengarah pada kerjasama, saling ketergantungan yang positif dapat terpenenuhi.

Berdasarkan hasil temuan pada penelitian ini menunjukkan bahwa model pembelajaran koperatif tipe tipe students team achievement division efektif dalam meningkatkan aktivitas dan hasil belajar kognitif siswa. Penelitian ini sejalan dengan penelitian yang dilakukan oleh Lubis (2012) yang menyatakan bahwa model pembelajaran koperatif tipe tipe students team achievement division memiliki pengaruh signifikan terhadap hasil belajar fisika siswa SMA. Beberapa penelitian juga menunjukkan bahwa model pembelajaran koperatif tipe tipe students team achievement division memiliki dampak positif terhadap aktivitas dan hasil belajar siswa (Putri, 2009; Karniawati, 2011; Brutu \& Simarmata, 2014). Pembelajaran koperatif tipe tipe students team achievement division adalah salah satu tipe model pembelajaran koperatif yang menggunakan kelompok-kelompok kecil secara heterogen tanpa membedakan ras, suku, dan agama (Lubis, 2012). Model pembelajaran koperatif tipe tipe students team achievement division merupakan model pembelajaran koperatif yang paling sederhana yang cocok digunakan oleh guru, diman pada pembelajaran tersebut dapat memacu atau mendorong siswa untuk saling membantu antara siswa yang satu dengan siswa yang lain agar siswa dapat memahami materi yang telah diajarkan oleh guru (Brutu \& Simarmata, 2014).

\section{SIMPULAN DAN SARAN}

Berdasarkan hasil penelitian yang telah dilakukan dapat disimpulkan bahwa dengan menggunakan model pembelajaran kooperatif tipe students team achievement division terjadi peningkatan aktivitas dan hasil belajar koginitif siswa kelas VIII MTs. Aisyiyah Sungguminasa Kab. Gowa. Aktivitas belajar biologi siswa dengan penerapan model kooperatif tipe students team achievement division adalah sebesar $66,80 \%$ dan hasil belajar biologi siswa kelas VIII MTs. Aisyiyah Sungguminasa Kab. Gowa dengan penerapan model pembelajaran kooperatif tipe students team achievement division masuk dalam kategori sangat tinggi dengan 
rata-rata sebesar $85,5 \%$. Perlu penelitian lebih lanjut tentang penerapan model pemebelajaran students team achievement division dengan menggunakan lebih dari 1 kelas yang ada di MTs. Aisyiyah Sungguminasa Kab. Gowa dan menggunakan metode kuasi eksperimen serta materi pelajaran yang berbeda sehingga model tersebut benar-benar dapat disarankan untuk dipergunakan oleh pendidik di Kab. Gowa.

\section{UCAPAN TERIMA KASIH}

Ucapan terima kasih disampaikan kepada semua pihak yang telah mendukung kegiatan penelitian sehingga penelitian dapat berjalan dengan baik dan lancar.

\section{RUJUKAN}

Andriani, N., M., S., Natajaya, I. N., \& Sunu, I., G., K., A. (2014). Pengaruh Model Pembelajaran Kooperatif Tipe STAD Terhadap Hasil Belajar Bahasa Indonesia Ditinjau Dari Motivasi Belajar Siswa. Jurnal Administrasi Pendidikan Indonesia, 5(1), 1-10. Retrieved from http://oldpasca.undiksha.ac.id/e-journal/index.php/ jurnal_ap/article/view/1182

Arikunto, Suharsimi. (2005). Dasar-dasar Evaluasi Pendidikan. Jakarta: Bina Aksara.

Asmani, Jamal Ma'mur. (2011). Tuntunan Lengkap Metodologi Praktis Penelitian Pendidikan. Jogjakarta. Diva Press.

Brutu, S.,U., \& Simarmata. (2014). Pengaruh Model Pembelajaran Kooperatif Tipe STAD Terhadap Hasil Belajar Fisika di SMP. Jurnal Inpafi, 2(1), 154-162. Retrieved https://jurnal.unimed.ac.id/2012/index.php/inpafi/article/view/1973

Endaningsih, N., Maaryani, S., \& Sukawimani, S.,S. (2012). Peningkatan Hasil Belajar Biologi Dengan Pendekatan Kooperatif Tipe JIGSAW pada Siswa Kelas XI IPA 1 SMA 97 Jakarta. Jurnal Formatif, 2(1), 10-22. http://dx.doi.org/ 10.30998/formatif.v2i1.83

Kaniawati, I. (2011). Penerapan Model Pembelajaran Kooperatif Tipe STAD (Student Teams Achievement Divisions) untuk Meningkatkan Penguasaan Konsep Fisika Siswa SMP. Jurnal Sains, 40(1). Retrieved from http://journal.um.ac.id /index.php/sains/article/view/3491

Lubis, A. (2012). Pengaruh Model Pembelajaran Kooperatif Tipe STAD Terhadap Hasil Belajar Fisika Siswa Pada Materi Pokok Gerak Lurus di Kelas X SMA Swasta UISU Medan. Jurnal Pendidikan Fisika, 1(1), 27-32. https://doi.org/ 10.22611/jpf.v1i1.3378

Purba, R.F. (2011). Pengaruh Model Pembelajaran Koopeeratif Tipe STAD (Student Team Achievement Divisions) Terhadap Hasil Belajar Siswa Pada Materi Pokok Wujud Zat dan Massa Jenis di Kelas VII Semester II SMP Negeri 2 Galang Tahun Pembelajaran 2010/2011, Skripsi, FMIPA, Unimed, Medan.

Putri, H. E. (2012). Pengaruh Pembelajaran Kooperatif Tipe STAD (Student Teams Achievement Divisions) dengan Metode Peta Konsep terhadap Hasil Belajar Siswa pada Sub Pokok Bahasan Energi di SMP Negeri 1 Laren Lamongan. Jurnal Inovasi Pendidikan Fisika, 1(1), 25-28. Retrieved from https://jurnalmahasiswa.unesa.ac.id/index.php/inovasi-pendidikan-fisika/article/ view/348

Riyanto, R., \& Susilawati, L. (2019). Penerapan Media Aurora Animasi 3d Maker Untuk Meningkatkan Hasil Belajar Kognitif Mahasiswa Biologi IKIP Budi Utomo 
Malang. Edubiotik : Jurnal Pendidikan, Biologi dan Terapan, 4(01), 52-57. https://doi.org/10.33503/ebio.v4i01.438

Slavin, R.E. (1995). Cooperative Learning Theory, Research and Practice. Second Edition. Boston: Allyn and Bacon. Retrieved from https://www.researchgate. net/publication

Suardi., Marhaeni, \& Dantes. (2014). Pengaruh Model Pembelajaran Kooperatif Tipe STAD Terhadap Hasil Belajar. Retrieved from http://repository.uinsu.ac.id/4413/ 1/SKRIPSI\%20MASTARI\%20FIX.pdf

Wiriaatmadja, Rochiati. (2008). Metode Penelitian Tindakan Kelas. PT. Remaja Rosdakarya. Bandung. 